\title{
Justiciability of Economic, Social and Cultural Rights under International Human Rights Law
}

\author{
Muhammad Ekramul Haque \\ Professor, Department of Law, University of Dhaka, Bangladesh
}

\section{INTRODUCTION}

Human rights emerged at the international level as an indivisible concept. The Universal Declaration of Human Rights (UDHR) ${ }^{1}$ included civil and political (CP) and economic, social and cultural (ESC) rights in a single document. The two covenants, the International Covenant on Civil and Political Rights (ICCPR $)^{2}$ and the International Covenant on Economic, Social and Cultural Rights (ICESCR) ${ }^{3}$ recognized in particular, the interdependent character of civil and political (CP) rights and economic, social and cultural (ESC) rights. The indivisible character of all human rights has been further endorsed by various international documents. ${ }^{4}$

However, in spite of repeated declarations of the equal importance of both groups of human rights, much less attention had been paid to the development of enforcement mechanisms for ESC rights than for CP rights. The ICESCR did not contain an adjudicatory enforcement mechanism like the Optional Protocol to the ICCPR. This reflected the notion that ESC rights could not or should not be made justiciable. This approach towards ESC rights created a 'gap' between CP rights and ESC rights in terms of enforcement, which was arguably created 'for political and not for legal reasons'. However, developments regarding ESC rights and their enforcement since the adoption of the ICESCR in 1966 have operated to bring both sets of human rights to a closer if not equal footing. In particular, developments during the last two decades have improved the status of ESC rights significantly, and have notably closed the 'gaps' between CP rights and ESC rights in terms of their enforcement. These developments have created a strong foundation for justiciability of the ICESCR rights. The objective of this article is to determine the present status of the enforceability and especially justiciability of ICESCR rights under international human rights law at international and regional levels.

UNGA Res 217A (III) (10 December 1948) UN Doc A/810 ('UDHR').

Opened for signature 19 December 1966, 999 UNTS 171 (entered into force 23 March 1976) ('ICCPR').

Opened for signature 16 December 1966, 993 UNTS 3 (entered into force 3 January 1976) ('ICESCR').

4 See, for example, Vienna Declaration and Programme of Action, UN GAOR (12 July 1993) UN Doc. A/CONF.157/23.

5 Christian Courtis, International Commission of Jurists, Courts and the Legal Enforcement of Economic, Social and Cultural Rights: Comparative Experiences of Justiciability (International Commission of Jurists 2008) 1 ('ICJ Book'). 


\section{JUSTICIABILITY IN PRACTICE: INTERNATIONAL LEVEL}

\section{A. ESC rights and the CESCR}

There is no formal judicial body established at the international level to deal with enforcement of the ESC rights. However, the Committee on economic, Social and Cultural Rights (CESCR) has been enjoying the power to monitor the performance of States Parties through the reporting system under the ICESCR. The CESCR after receiving reports from and conducting dialogues with States Parties, issues 'concluding observations.' The CESCR makes a general evaluation of a State's performance of its ICESCR obligations. Moreover, the CESCR has simultaneously been developing the content of rights and obligations regarding the ESC rights. The views and observations of the CESCR are not binding upon the parties in a strictly concrete legal sense, but they have not been patently disregarded by states. No State Party has for example expressly denied the authority of the CESCR. Thus, the CESCR has occupied, by long practice, a tangible place in the enforcement of the ESC rights at the international level through the reporting system. ${ }^{6}$ In its concluding observations, the CESCR has identified violations, expressed its concern, and has made suggestions and recommendations for appropriate reforms. For example, in concluding observations on the United Kingdom, the CESCR concluded that 'failure to incorporate the right to strike into domestic law constitute[d] a breach of article 8 of the Covenant. ${ }^{7}$ In the concluding observations on the Hong Kong Special Administrative Region (China), the CESCR said that 'the failure by HKSAR [Hong Kong Special Administrative Region] to prohibit race discrimination in the private sector constitute[d] a breach of its obligations under article 2 of the Covenant. ${ }^{8}$ The CESCR identified certain laws as being in 'flagrant violation' of the ICESCR, the committee was deeply concerned that the Government of Cameroon had not yet initiated legal reforms in regard to the repealing of laws regarding the unequal status quo of women, notably in the aspects of the Civil Code and the Commercial Code, where, among other sections, the right to own property and legislations which govern credit and bankruptcy, which in essence restrict women's access to the means of production. ${ }^{9}$ These laws are, in the opinion of

6 Allan Rosas \& Martin Scheinin, 'Implementation Mechanisms and Remedies' in A. Eide et al. (eds), Economic, Social and Cultural Rights (Kluwer Law International, $2^{\text {nd }}$ ed, 2001) 425, 427. Scheinin and Rosas commented: 'In fact, the Committee on Economic, Social and Cultural Rights has, in the absence of an official complaint procedure, developed its functions under the reporting procedure to something which is more and more resembling a quasi-judicial complaint procedure.'

7 Committee on Economic, Social and Cultural Rights (CESCR), Consideration of Reports Submitted by States Parties under Articles 16 and 17 of the Covenant: Concluding Observations of the Committee on Economic, Social and Cultural Rights: United Kingdom of Great Britain and Northern Ireland (5 June 2002) $28^{\text {th }}$ sess, $25^{\text {th }} \mathrm{mtg}$, UN Doc E/C.12/1/Add.79, para 16.

8 Committee on Economic, Social and Cultural Rights (CESCR), Consideration of Reports Submitted by States Parties under Articles 16 and 17 of the Covenant: Concluding Observations of the Committee on Economic, Social and Cultural Rights: China: Honk Kong Special Administrative Region (21 May 2001) $29^{\text {th }} \mathrm{mtg}$, UN Doc E/C.12/1/Add. 58 , para 30.

9 Committee on Economic, Social and Cultural Rights (CESCR), Consideration of Reports Submitted by States Parties under Articles 16 and 17 of the Covenant: Concluding Observations of the Committee on Economic, Social and Cultural Rights: Cameroon (8 December 1999) $54^{\text {th }} \mathrm{mtg}$, UN Doc E/C.12/1/Add.40, para 13.

Page $\mid 40$ 
the committee, in deep violation of the non-discrimination and unequal treatment provisions of the Covenant and do not in any way align with the recently amended Constitution of Cameroon which upholds the equal rights of each and every Cameroon citizen. ${ }^{10}$ A particular act of Cyprus was condemned by the CESCR as a 'serious violation' of certain ICESCR provisions, as it said:

The Committee is alarmed by the allegations of inhuman or degrading treatment of mentally ill patients in some health institutions. It stresses that such a situation constitutes a serious violation of the State Party's obligations under articles 2 and $12 .{ }^{11}$

Thus, the CESCR not only expressed its concerns, but also identified breaches of the ICESCR. It is true that the activities of the CESCR do not prove the justiciability of the ESC rights in a strictly legal sense. However, it undoubtedly has created building blocks for justiciability of the ESC rights at the international level, which will lead towards the justiciability in a strictly legal sense. Shany has argued that " $[\mathrm{t}] \mathrm{he}$ normative and institutional post-1966 developments ... underlie the claim that [Economic and Social Rights] are nowadays internationally justiciable as a matter of legal methodology, in the sense that there exist reasonably clear legal criteria for their implementation, which entail politically acceptable consequences. ${ }^{12}$

\section{B. Optional protocol to the ICESCR}

Recently, an Optional Protocol to the ICESCR ${ }^{13}$ has been adopted by consensus ${ }^{14}$ in the UN General Assembly on 10 December 2008, a landmark step on the way of making ESC rights enforceable. The Protocol 'shall enter into force three months after the date of the deposit with the Secretary-General of the United Nations of the tenth instrument of ratification or accession. ${ }^{15}$ The Optional Protocol, once it comes into force, will allow persons to make complaints regarding violations of ESC rights contained in the ICESCR to the CESCR. ${ }^{16}$ It gives a new quasi-judicial adjudicatory

10 Ibid.

11 Committee on Economic, Social and Cultural Rights (CESCR), Consideration of Reports Submitted by States Parties under Articles 16 and 17 of the Covenant: Concluding Observations of the Committee on Economic, Social and Cultural Rights: Cyprus (4 December 1998) $34^{\text {th }}, 35^{\text {th }}$ and $36^{\text {th }} \mathrm{mtg}$, UN Doc E/C.12/1/Add.28, para 16.

12 Yuval Shany, 'Stuck in a Moment in Time: The International Justiciability of Economic, Social and Cultural Rights' in Daphne Barak-Erez and Aeyal M Gross (eds), Exploring Social Rights (Hart Publishing 2007) 77, 81.

13 Optional Protocol to the International Covenant on Economic, Social and Cultural Rights (10 December 2008) UNGA Res 63/117, UN GAOR, 63 ${ }^{\text {rd }}$ sess, $66^{\text {th }}$ plen mtg, Agenda Item 58, UN Doc A/RES/63/117 opened for signature 24 September 2009 (not yet in force) ('Optional Protocol to the ICESCR').

14 Catarina de Albuquerque, 'Chronicle of an Announced Birth: The Coming into Life of the Optional Protocol to the International Covenant on Economic, Social and Cultural Rights-The Missing Piece of the International Bill of Human Rights' (2010) 32 Human Rights Quarterly 144, 177. Optional Protocol to the ICESCR art 18(1).

16 The CESCR will be entitled to receive individual communications, group communications and interstate communications. (Ibid arts 1,2 and 10). 
function to the CESCR. ${ }^{17}$ The Optional Protocol, adopted in the long 'road towards an international complaints mechanism for ESC rights, ${ }^{, 18}$ will 'dispel claims that ESC rights under the ICESCR were not intended to be justiciable.' 19 'It will enable victims to seek justice for violations of their economic, social and cultural rights at the international level for the first time. ${ }^{20}$ It closes a yawning gap between the ICCPR and the ICESCR ${ }^{21}$ which 'will break down the walls of division that history built and will unite once again what the Universal Declaration of Human Rights proclaimed as a sole body of human rights sixty years ago. ${ }^{22}$

\section{Indivisibility of human rights: Enforcement of the ESC rights through the Human Rights Committee (HRC)}

The indivisible nature of all human rights has led to the enforcement of some ESC rights by way of the enforcement of related CP rights. ESC rights have been the subject of some quasi-judicial enforcement in certain cases before the Human Rights Committee (HRC), the body which monitors implementation of the ICCPR. For example, in Broeks $v$ Netherlands,${ }^{23}$ Mrs Broeks lodged a complaint on the ground of alleged violation of article 26 of the ICCPR, which guarantees equality before the law, the equal protection of the law, and also prohibits discrimination on any ground. Her complaint concerned the Dutch law regarding eligibility for unemployment benefits. She contended that a provision of the said law was discriminatory on the ground of sex and status: a married woman was deprived of continued unemployment benefits unless she could prove she was the family "breadwinner", while a man in her position received the benefits irrespective of his marital or breadwinner status. The Netherlands argued that the complainant's right in question was related to social security rights and therefore fell under the ICESCR rather than the ICCPR. Thus, the Government argued that the complaint was inadmissible, as the ICESCR had its own distinct mechanism of monitoring state obligations which did not contain any complaint procedure.

The HRC decided the complaint in favour of the complainant taking a stand in support

17 Claire Mahon, 'Progress at the Front: The Draft Optional Protocol to the International Covenant on Economic, Social and Cultural Rights' (2008) 8 Human Rights Law Review 617, 617.

${ }^{18}$ Arne Vandenbogaerde and Wouter Vandenhole, 'The Optional Protocol to the International Covenant on Economic, Social and Cultural Rights: An Ex-Ante Assessment of its Effectiveness in Light of the Drafting Process' (2010) 10 Human Rights Law Review 207, 237.

${ }^{19}$ Manisuli Ssenyonjo, 'Economic, social and cultural rights: an examination of state obligations' in Sarah Joseph and Adam McBeth (eds), Research Handbook on International Human Rights Law (Edward Elgar 2010) 36, 36.

${ }^{20}$ Navanethem Pillay, Statement at the Signing Ceremony for the Optional Protocol to the International Covenant on Economic, Social and Cultural Rights (UNHCR, 24 September 2009) <http://www.unhchr.ch/huricane/huricane.nsf/view01/5EE2E0E5168886FCC125763B00589EF3?op endocument> accessed 04 March 2021.

${ }^{21}$ Malcolm Langford, 'Closing the Gap? An Introduction to the Optional Protocol to the International Covenant on Economic. Social, and Cultural Rights' (2009) 27 Nordic Journal on Human Rights 1, 2.

${ }^{22}$ Statement made by Miguel d'Escoto Brockmann, President of the $63^{\text {rd }}$ session of the United Nations General Assembly, in adopting the Optional Protocol to the ICESCR (10 December 2008) UN GAOR, 63rd Session, 66 ${ }^{\text {th }}$ plen mtg, Agenda item 58 (continued) UN Doc A/63/PV.66.

23 Human Rights Committee (HRC), Views: Communication No. 172/1984, $29^{\text {th }}$ sess, UN Doc CCPR/C/OP/2 at 196 (1990) ('Broeks').

Page $\mid 42$ 
of application of article 26, in spite of the overlapping of the provisions of the ICCPR and ICESCR:

The State party contends that there is considerable overlapping of the provisions of article 26 with the provisions of article 2 of the International Covenant on Economic, Social and Cultural Rights. The Committee is of the view that the International Covenant on Civil and Political Rights would still apply even if a particular subject-matter is referred to or covered in other international instruments, for example, the International Convention on the Elimination of All Forms of Racial Discrimination, the Convention on the Elimination of All Forms of Discrimination against Women, or, as in the present case, the International Covenant on Economic, Social and Cultural Rights. $^{24}$

While the Broeks decision was controversial, it was supported subsequently by the HRC in the General Comment $18 .^{25}$ The HRC commented:

While article 2 limits the scope of the rights to be protected against discrimination to those provided for in the Covenant, article 26 does not specify such limitations. That is to say, article 26 provides that all persons are equal before the law and are entitled to equal protection of the law without discrimination, and that the law shall guarantee to all persons equal and effective protection against discrimination on any of the enumerated grounds. In the view of the Committee, article 26 does not merely duplicate the guarantee already provided for in article 2 but provides in itself an autonomous right. It prohibits discrimination in law or in fact in any field regulated and protected by public authorities. Article 26 is therefore concerned with the obligations imposed on States parties in regard to their legislation and the application thereof. Thus, when legislation is adopted by a State party, it must comply with the requirement of article 26 that its content should not be discriminatory. In other words, the application of the principle of nondiscrimination contained in article 26 is not limited to those rights which are provided for in the Covenant. ${ }^{26}$

Thus, it appears that the non-discrimination guarantee in article 26 of the ICCPR is wide enough in its scope so as to include rights incorporated in the ICESCR. To the extent that it does, it resembles Article 2(2) of the ICESCR.

In interpreting the right to life, the HRC said:

Moreover, the Committee has noted that the right to life has been too often narrowly interpreted. The expression 'inherent right to life' cannot properly be

24 Ibid [12.1].

25 Sarah Joseph, Jenny Schultz and Melissa Castan, The International Covenant of Civil and Political Rights: Cases, Material and Commentary ( $2^{\text {nd }}$ edn, Oxford University Press 2004) 686.

26 Human Rights Committee (HRC), CCPR General Comment No. 18: Non-discrimination, $37^{\text {th }}$ sess, (10 November 1989) paragraphs 7-8 ('General Comment 18 of the HRC') in Compilation of General Comments and General Recommendations Adopted by Human Rights Treaty Bodies, UN Doc HRI/GEN/1/Rev.6 (2004) 146. 
understood in a restrictive manner, and the protection of this right requires that States adopt positive measures. In this connection, the Committee considers that it would be desirable for States parties to take all possible measures to reduce infant mortality and to increase life expectance, especially in adopting measures to eliminate malnutrition and epidemics. ${ }^{27}$

In E.H.P. $v$ Canada ${ }^{28}$ the HRC recognized the ESC rights dimension of article 6 of the ICCPR which recognises the right to life. The author of the communication argued that the dumping of nuclear waste within the confines of a town of 10,000 inhabitants caused 'a threat to the life of present and future generations.' While the HRC rejected the admissibility of the communication on the ground of a failure to exhaust domestic remedies, it explicitly recognized the socio-economic aspects of article 6 of the ICCPR by admitting that the said communication raised 'serious issues, with regard to the obligation of States parties to protect human life. ${ }^{29}$

Again, HRC has also addressed ESC aspects of article 6 in its Concluding Observations. For example, in its Concluding Observation on Canada, the HRC observed: ${ }^{30}$

The Committee is concerned that homelessness has led to serious health problems and even to death. The Committee recommends that the State party take positive measures required by article 6 to address this serious problem.

Article 24 of the ICCPR is another instance which has been interpreted to have significant ESC rights aspects. Article 24(1) of the ICCPR provides rights of protection and non-discrimination for children. The HRC in its General Comment 17 recognized that the requisite measures of protection for children included steps to ensure certain ESC rights for children: 'For example, every possible economic and social measure should be taken to reduce infant mortality and to eradicate malnutrition among children and to prevent them from being subjected to acts of violence and cruel and inhuman treatment or from being exploited by means of forced labour or prostitution, or by their use in the illicit trafficking of narcotic drugs, or by any other means. ${ }^{, 31}$

The HRC in General Comment 17 also emphasized on taking all possible measures to provide the children "with a level of education that will enable them to enjoy the rights

27 Human Rights Committee (HRC), CCPR General Comment No. 6: Right to Life, $16^{\text {th }}$ sess, (1982) ('General Comment 6 of the HRC') in Compilation of General Comments and General Recommendations Adopted by Human Rights Treaty Bodies, UN Doc HRI/GEN/1/Rev.6 (2004) 128. Human Rights Committee (HRC), Views: Communication No. 67/1980, $17^{\text {th }}$ sess, not previously published in the annual report of the Human Rights Committee ('E.H.P. $v$ Canada') <http://www.bayefsky.com/pdf/114_canada67_1980.pdf >.

29 Ibid para 8.

30 Human Rights Committee (HRC), Consideration of Reports Submitted by States Parties under Article 40 of the Covenant: Concluding observations on Canada (7 April 1999) $65^{\text {th }} \mathrm{sess}, 1747^{\text {th }} \mathrm{mtg}$, UN Doc CCPR/C/79/Add.105, para 12.

31 Human Rights Committee (HRC), CCPR General Comment No. 17: Article 24 (Rights of the child), $35^{\text {th }}$ sess, (1989) ('General Comment 17 of the HRC') in Compilation of General Comments and General Recommendations Adopted by Human Rights Treaty Bodies, UN Doc HRI/GEN/1/Rev.6 (2004) 144).

Page $\mid 44$ 
recognized in the Covenant. ${ }^{32}$ Thus, while the right to education is a right of ESC nature, 'it is essential to ensure the capacity to exercise civil and political rights, and is therefore an important component of article 24 protection. ${ }^{33}$ The Concluding Observations regarding Zambia reflected this stand of the HRC, where the HRC said that it was 'concerned that no measures [were] taken to ensure that pregnancy or parenthood do not affect the continuous education of children. ${ }^{34}$

Thus, it appears from the above discussion that while the HRC is tasked with enforcing $\mathrm{CP}$ rights under the ICCPR, it has addressed ESC aspects of certain ICCPR provisions such as those in articles 6, 24 and 26. The indivisible character of human rights has led the HRC to necessarily address some ESC rights in enforcing certain CP rights.

It appears that ESC rights have already become justiciable in different forms at the international level. The rights have been subject to quasi-judicial proceedings of the CESCR or have been enforced by the HRC as all human rights are indivisible. Moreover, once the Optional Protocol to the ICESCR comes into force, there will clearly be a quasi-judicial enforcement mechanism to enforce the ICESCR rights. This discussion reveals that there is now no legal or normative barrier to enforce the ESC rights.

\section{JUSTICIABILITY OF ESC RIGHTS IN REGIONAL HUMAN RIGHTS SYSTEMS}

ESC rights have been judicially enforced in different regional human rights systems. For example, in Europe, ESC rights have been judicially enforced by the European Court of Human Rights (ECHR). The European Convention of Human Rights ${ }^{35}$ does not have a set of direct provisions on ESC rights, but the ECHR has enforced certain ESC rights relying on the indications to them found in the related provisions of the Convention. For example, Article 8 gives protection to one's own home, though it does not specifically lay down a housing right. Nevertheless, the ECHR enforced the right to housing based on Article 8 of the European Convention in Moldovan v Romania. ${ }^{36}$ In this case, the houses of some Romanian inhabitants were destroyed by police action. ${ }^{37}$ The applicants submitted that 'after the destruction of their houses, they could no longer enjoy the use of their homes and had to live in very poor, cramped conditions, ${ }^{38}$ in violation of, inter alia, article 8 of the European Convention. In assessing the complaint, the Court said:

\footnotetext{
32 Ibid para 3.

${ }^{33}$ Sarah Joseph, Jenny Schultz and Melissa Castan, The International Covenant of Civil and Political Rights: Cases, Material and Commentary ( $2^{\text {nd }}$ ed, Oxford University Press 2004) 686.

${ }^{34}$ Human Rights Committee (HRC), Consideration of Reports Submitted by States Parties under Article 40 of the Covenant: Concluding observations on Zambia (3 April 1996) $56^{\text {th }} \mathrm{sess}, 1498^{\text {th }} \mathrm{mtg}$, UN Doc CCPR/C/79/Add.62, para 17.

${ }^{35}$ Convention for the Protection of Human Rights and Fundamental Freedoms, opened for signature 4 November 1950, ETS No 5 (entered into force on 3 September 1953) ('European Convention').

${ }^{36}$ Moldovan v Romania [2005] VII Eur Court HR 167 ('Moldovan v Romania').

${ }^{37}$ Ibid [89].

${ }^{38}$ Ibid [88].
} 
In the present case, there is no doubt that the question of the applicants' living conditions falls within the scope of their right to respect for family and private life, as well as their homes. Article 8 is thus clearly applicable to these complaints. ${ }^{39}$

The Court noted that some houses were not rebuilt at the date of the judgment, and that some houses were rebuilt, but were 'uninhabitable'. ${ }^{40}$ Adding that most of the applicants could not return to their village till the date of the judgment, who were living 'scattered throughout Romania and Europe, ${ }^{, 41}$ the Court concluded that 'the repeated failure of the authorities to put a stop to breaches of the applicants' rights, amount[ed] to a serious violation of Article 8 of the Convention of a continuing nature. ${ }^{42}$ The Court unanimously held that there were violations of different articles of the European Convention of Human Rights including Article 8, and the State had to pay sums of different amount, fixed by the Court, to the applicants. ${ }^{43}$

Despite the absence of a clear set of provisions regarding ESC rights in the Convention, the attitude of the Court towards them was positive, as Luke concluded:

In relation to complaints that disclose gross failures of the most basic socioeconomic support, the Court's starting point is now an unequivocal acceptance of the view that the Convention protects a core irreducible set of such rights. ${ }^{44}$

The European Social Charter ${ }^{45}$ is the main treaty on ESC rights in Europe. However, the Charter has neither an individual complaint system nor any court with jurisdiction to deal with violations unlike the European Convention of Human Rights. The two mechanisms provided by the European Social Charter are the reporting procedure ${ }^{46}$ and the collective complaint system. ${ }^{47}$ The European Committee of Social Rights (ECSR) is the body which regulates both the mechanisms of the Charter. Although the ECSR is a body subordinate to the Council of Ministers, it is 'the only body that is competent to give an authoritative interpretation of the Charter. ${ }^{48}$ In interpreting the provisions of the European Charter, the ECSR considers the Charter to be a 'living instrument' and has adopted a liberal approach to interpreting Charter provisions in the light of

39 Ibid [105].

40 Ibid $[107(\mathrm{~g})]$.

$41 \quad$ Ibid $[107(\mathrm{~h})]$.

42 Ibid [109].

43 Ibid 197.

44 Luke Clements and Alan Simmons, 'European Court of Human Rights' in Malcolm Langford (ed), Social Rights Jurisprudence: Emerging Trends in International and Comparative Law (Cambridge University Press 2008) 409, 426.

45 European Social Charter (revised), opened for signature 3 May 1996, ETS No 163 (entered into force on 1 July 1999) ('European Charter').

46 It was introduced when the Charter was first adopted in 1961. It is compulsory.

47 It was added only in 1995 by an Optional Protocol to the Charter. However, this is an optional mechanism for the State Parties.

48 Urfan Khaliq and Robin Churchill, 'The European Committee of Social Rights' in Malcolm Langford (ed), Social Rights Jurisprudence: Emerging Trends in International and Comparative Law (Cambridge University Press 2008) 428, 428.

Page $\mid 46$ 
developments in domestic and international laws. ${ }^{49}$ The ECSR has concretised the different broadly drafted provisions, and has emphasized the need for appropriate legislative protection for Charter rights rather than protection via mere administrative practices. $^{50}$

The collective complaint system "established an "increasingly judicial" procedure, and gave the ECSR the status of a "quasi-judicial body". 51 For example, in The International Federation of Human Rights Leagues (FIDH) v. France, ${ }^{52}$ the ECSR enforced article 17 of the European Charter which deals with the right to social, legal and economic protection of children and young persons. ${ }^{53}$ The government had curtailed the medical benefits of illegal immigrants, which was challenged by the complainant on the ground, inter alia, of a violation of article 17 of the European Charter. The ECSR found that the new law limited medical assistance to the children and young persons of illegal immigrants in France to situations that involved an immediate threat to life ${ }^{54}$ It also found that the children of illegal immigrants could only be admitted to the medical assistance scheme after a certain time. ${ }^{55}$ A majority of the ECSR held that there was a violation of article 17. This was a case of direct enforcement of a right guaranteed under the European Social Charter. The ECSR did not rely on or make its decision in reliance upon any right of $\mathrm{CP}$ nature such as the right to non-discrimination.

Despite some lingering questions ${ }^{56}$ regarding the effectiveness of the collective

49 Ibid 433.

50 Ibid 434

51 Virginia Mantouvalou and Panayotis Voyatzis, 'The Council of Europe and the protection human rights: a system in need of reform' in Sarah Joseph and Adam McBeth (eds), Research Handbook on International Human Rights Law (Edward Elgar 2010) 326, 339.

52 The International Federation of Human Rights Leagues (FIDH) v France [2005] 40 EHRR SE 25, 231 ('FIDH v France').

53 Article 17 of the European Social Charter states:

'With a view to ensuring the effective exercise of the right of children and young persons to grow up in an environment which encourages the full development of their personality and of their physical and mental capacities, the Parties undertake, either directly or in co-operation with public and private organisations, to take all appropriate and necessary measures designed:

1.

a. to ensure that children and young persons, taking account of the rights and duties of their parents, have the care, the assistance, the education and the training they need, in particular by providing for the establishment or maintenance of institutions and services sufficient and adequate for this purpose;

b. to protect children and young persons against negligence, violence or exploitation;

c. to provide protection and special aid from the state for children and young persons temporarily or definitively deprived of their family's support;

2. to provide to children and young persons a free primary and secondary education as well as to encourage regular attendance at schools.

55

56

FIDH v France [2005] 40 EHRR SE 25, 231, 238-39 [36].

Ibid.

For example, an individual petition system would arguably be more effective rather than the collective complaint system. For criticism of this system, see P Alston, 'Assessing the Strengths and Weaknesses of the European Social Charter's Supervisory System' in G de Burca and B de Witte (eds) Social Rights in Europe (Oxford University Press 2005) 45; R Churchill and U Khaliq, 'The Collective Complaints System of the European Social Charter: An Effective Mechanism for Ensuring 
complaint system, it has been identified as 'a promising development, as it reflects a belief that socio-economic entitlements are justiciable. ${ }^{57}$

In the American region, the Organization of American States (OAS) first established the Inter-American Commission on Human Rights (Commission) to deal with complaints regarding violations of human rights contained in different human rights instruments including the American Declaration of the Rights and Duties of Man (American Declaration) ${ }^{58}$ the American Convention on Human Rights (American Convention) $)^{59}$ and the Addition Protocol to the American Convention in the Area of Economic, Social, Cultural Rights (Protocol of San Salvador) ${ }^{60}$ These instruments contain, inter alia, different ESC rights. The Commission does not have any jurisdictional bar to enforce ESC rights; rather it has the equal power to enforce all types of human rights recognized therein. Thus, the Commission in dealing with complaints regarding violations of different ESC rights has enforced them without any hesitation. For example, in the case of Coulter et al. Case v. Brazil, ${ }^{61}$ the Commission enforced the right to health contained in Article XI of the American Declaration. In this case, the construction of a new highway in a remote area resulted into spread of serious new diseases among the people of that area. Due to the failure of the Brazilian Government to protect the people from the injury to their health, "the Commission found the government internationally responsible under Declaration Article XI for violating the right to health. ${ }^{62}$

The OAS subsequently established the Inter-American Court of Human Rights (IACHR), an 'autonomous judicial institution', ${ }^{63}$ in 1979. The IACHR has jurisdiction to deal with cases of human rights violations under different human rights treaties including the American Convention and the Protocol of San Salvador, which deals with ESC rights extensively. There was nothing in the Convention or the Protocol which prevented judicial enforcement. The Court's jurisdiction was also not differentiated on the basis of any division of human rights into CP rights and ESC rights. Thus, different ESC rights have been judicially enforced by this Court in the American region.

The right to a pension was judicially enforced by the IACHR in Five Pensioners $v$

Compliance with Economic and Social Rights?' (2004) 15 European Journal of International Law 417.

57 Mantouvalou and Voyatzis (n 51) 341.

58 OAS. Res. XXX, International Conference of American States, 9th Conf., O.A.S. Doc. OEA/Ser. L.V/I.4 Rev. XX (1948).

59 American Convention on Human Rights, opened for signature 22 November 1969, Text: OAS, Treaty Series No. 69 (entered into force 18 July 1978).

60 Addition Protocol to the American Convention in the Area of Economic, Social, and Cultural Rights, opened for signature 17 November 1988, Text: OAS, Treaty Series No. 69 (entered into force 16 November 1999).

61 Inter-American Commission on Human Rights, Case 7615, Inter Am. Comm. H.R. (1985) OEA/Ser.L/V/II.66, doc. 10 rev. 1.

62 Tara J. Melish, 'The Inter-American Commission on Human Rights: Defending Social Rights Through Case-Based Petitions' in Malcolm Langford (ed), Social Rights Jurisprudence: Emerging Trends in International and Comparative Law (Cambridge University Press 2008) 339, 352.

63 Statute of the IACHR, art 1.

Page $\mid 48$ 
Peru. ${ }^{64}$ The issue in the case was "whether the parameters used by the State to reduce or recalculate the amounts of the pensions of the alleged victims as of 1992 represented a violation' ${ }^{65}$ of the Convention. Though the Court had the choice of addressing the claim 'in terms of Article 26, which guarantees the right to social security, or Article 21 , which protects the right to property' ${ }^{66}$ it decided the case on the basis of Article 21 by treating the right to a pension as a part of the right to property ${ }^{67}$ The Court found that:

by arbitrarily changing the amount of the pensions that the alleged victims had been receiving and by failing to comply with the judicial ruling arising from their applications for protective measures [provided by the Peruvian Court earlier], the State violated the right to property embodied in Article 21 of the Convention. ${ }^{68}$

The Court finally decided that the State violated "the right to property embodied in Article 21 of the American Convention on Human Rights. ${ }^{, 69}$ Thus, while the Court did not provide the remedy under Article 26, it granted actual relief ${ }^{70}$ to the victims with regard to their right to a pension, a right which is predominantly related to the right to social security contained in Article 26 of the Convention.

The recent case of Acevedo Buendia $v$ Peru $^{71}$ had some similarities to the Five Pensioners case. The applicants,

who were all members of an Association for Discharged and Retired Employees of the Comptroller of Peru, complained that two judgments rendered by the Constitutional Court ... had not been complied with. The two decisions were crucial to the members of the Association as they ordered the Comptroller to reimburse the amounts of pensions owed after the Peruvian Government had arbitrarily reduced them through the adoption of various decree laws. $^{72}$

Thus, the said non-compliance affected the applicants' rights to social security embodied in article 26 of the Convention. But the violation of article 26 was not argued by the Commission following the trend in Five Pensioners case: 'The strategy used to

64 Inter-American Court of Human Rights, Series C No. 98 (2003) IACHR 1 (28 February 2003) ('Five Pensioners ').

${ }^{65}$ Ibid [94].

66 Tara J. Melish, 'The Inter-American Court of Human Rights: Beyond Progressivity' in Malcolm Langford (ed), Social Rights Jurisprudence: Emerging Trends in International and Comparative Law (Cambridge University Press 2008) 372, 399.

67 Five Pensioners, Inter-American Court of Human Rights, Series C No. 98 (2003) IACHR 1 (28 February 2003) [102].

68 Ibid [121].

69 Ibid [187].

70 Ibid [187].

71 Inter-American Court of Human Rights, Series C No. 98 (1 July 2009) ('Acevedo Buendia').

72 Laurence Burgorgue-Larsen, 'Economic and Social Rights' in Laurence Burgorgue-Larsen and Amaya Ubeda De Torres, The Inter-American Court of Human Rights (Oxford University Press 2011) 613,632 . 
present the arguments was no different to what had gone before. ${ }^{73}$ The IACHR determined that violations of the right to property and the right to judicial protection contained in, respectively, articles 21 and 25 of the American Convention, had been breached. Although the IACHR did not decide the case on the basis of article 26, the eventual effect of the decision of the IACHR was to protect the right to social security embodied in article 26. Furthermore, the IACHR made some important observations regarding article 26 and the justiciability of ESC rights in the case. The IACHR clarified the obligations regarding ESC rights:

Furthermore, it is pertinent to note that even though Article 26 is embodied in chapter III of the Convention, entitled "Economic, Social and Cultural Rights", it is also positioned in Part I of said instrument, entitled "State Obligations and Rights Protected" and, therefore, is subject to the general obligations contained in Articles 1(1) and 2 mentioned in chapter I (entitled "General Obligations"), as well as Articles 3 to 25 mentioned in chapter II (entitled "Civil and Political Rights"). ${ }^{74}$

The IACHR then added that it is appropriate to recall the interdependence that exists between civil and political rights and economic, social and cultural rights, since they should be fully understood as human rights, without any rank and enforceable in all the cases before competent authorities. ${ }^{75}$

With reference to General Comment No. 3 of the CESCR, the IACHR in the same line clearly declared that the 'regression is actionable when economic, social and cultural rights are involved. ${ }^{76}$ One commentator has since said that the "Acevedo Buendia ruling comes at the right time, when many misunderstandings and myths about economic and social rights are biting the dust. ${ }^{77}$ It is argued that the IACHR is at the forefront of progress, as the first international court to recognize that the obligation of non-regression of the part of States is actionable. ${ }^{78}$ In this case, the issue was not one of enforcement of article 26 but of the non-compliance of the judgments of the Constitutional Court, which mainly affected the right to judicial protection incorporated in article 25. Nevertheless, the decision of the IACHR, which included the observations on article 26 , 'is a quantum leap which should satisfy the demands of those tireless advocates of the justiciability of economic and social rights. ${ }^{, 79}$

In whatever way the courts enforced ESC rights, one thing that is clear is that they have been judicially enforced. The regional bodies have either relied on an indication given in a provision, as has happened in the case of ECHR, or have enforced ESC rights on the basis of an extended interpretation of CP provisions, as has happened in case of IACHR. The ECSR on the other hand, directly enforces provisions of the European

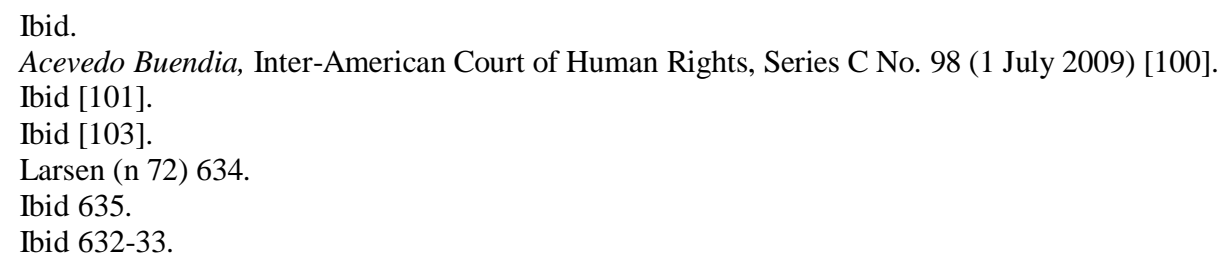

Page $\mid 50$ 
Social Charter. Indeed, the IACHR is also empowered to do so; it just has not done so yet. All of these regional developments support the simple conclusion that ESC rights are justiciable.

\section{JUSTICIABILITY OF ESC RIGHTS IN BANGLADESH}

A society, in which, fundamental human rights shall be secured for each and every citizen, such is a constitutional pledge taken by the Constitution of the People's Republic of Bangladesh. A part of the preamble of the Constitution entails, "Further pledging that it shall be a fundamental aim of the State to realise through the democratic process a socialist society, free from exploitation a society in which the rule of law, fundamental human rights and freedom, equality and justice, political, economic and social, will be secured for all citizens." Civil and political human rights have been vested in Part 3 of the Constitution as per international law and international human rights law norms, these rights seem to be the most shielded out of all the rights reserved in the Constitution. The power of the Constitution to not be contradicted through is vested in Article 7(2), which entails that no law can be made which violates any provision of the Constitution. The principle, that fundamental rights cannot be violated through making any legislation, is made known in Article 26. The fortified strength of both articles 7(2) and 26 provide the provisions of this part with multilayered protection. And again, in article 44(1), it is said that in case of any violation of any fundamental guaranteed in Part 3 of the Constitution will lead to the emergence of the right to seek judicial remedy. Along the same lines, Article 102(1) entails a special constitutional power to the High Court Division of the Supreme Court of Bangladesh to give any order or direction required for the enforcement of the fundamental rights, "The High Court Division on the application of any person aggrieved, may give such directions or orders to any person or authority, including any person performing any function in connection with the affairs of the Republic, as may be appropriate for the enforcement of any of the fundamental rights conferred by Part III of this Constitution."

Economic, social and cultural (ESC) rights, on the other hand, are marked to be judicially unenforceable fundamental principles of state policy (FPSP) in Part 2 of the Constitution of the People's Republic of Bangladesh. The state has some positive obligations towards all FPSP, as incorporated by Article 8(2), "The principles set out in this Part shall be fundamental to the governance of Bangladesh, shall be applied by the State in the making of laws, shall be a guide to the interpretation of the Constitution and of the other laws of Bangladesh, and shall form the basis of the work of the State and of its citizens." Very contrastingly however, it also incorporated that these principles 'shall not be judicially enforceable.' Parallel to ideas set down in 1966 by the International Covenant of Economic, Social and Cultural Rights (ICESCR), in regards of it containing no complaint mechanism.

In accordance to article 8(2), the rights remain judicially unenforceable, however, the very article has envisioned the implementation of the principles in ways other than judicial. Ways such as, them being fundamentally pivotal in the governance of Bangladesh, their paramount presence when legislating, and their ubiety when interpreting all laws and the Constitution. It is to be noted that, even though there is an 
express notion that ESC rights are judicially unenforceable, there is need the scope for there to be indirect enforcement. The Supreme Court of Bangladesh has laid out a series of interpretations of the right to life vested in article 32 to include ESC rights, as the right to life is judicially enforceable. A prime example of the right to life being used to judicially enforce ESC rights is Chairman, National Board of Revenue (NBR) Vs. Advocate Zulhas Uddin Ahmed and others. ${ }^{80}$ This case portrayed the right to medical care to be judicially enforceable, in the consideration that it too is a part of the right to life.

The door to negative enforcement of ESC rights is opened by Article 7(2), which says, 'This Constitution is, as the solemn expression of the will of the people, the supreme law of the Republic, and if any other law is inconsistent with this Constitution that other law shall, to the extent of the inconsistency, be void.' An example of the aforementioned negative enforcement is seen in Kudrat-E-Elahi Panirv Bangladesh, ${ }^{81}$ where the judge Naimuddin Ahmed J develops the scope of negative enforcement of FPSP. Article 7(2) opens up the pathway for there to be negative enforcement of FPSP, as it entails that no law can violate the principles laid out in the Constitution, therefore, as FPSP are part of the Constitution, there opens the door to negative enforcement. It can be agreed upon that this type of negative enforcement is viable, even though the positive enforcement has been taped off by article 8(2). In interpreting both article 7(2) and article 8(2), this very interpretation is key, as it strengthens their harmony by helping them come together, reduces possibilities of possible conflict between them and last but not least opens the door for the negative enforcement of ESC rights by regarding them as FPSP. It appears that the current spectrum of judicial trends in Bangladesh play to the tune of judicial enforceability of economic, social and cultural rights.

\section{CONCLUSION}

The contemporary legal dimensions regarding enforceability of the ESC rights indicate clearly that they are justiciable at the international and regional levels. Most importantly, many ESC rights have already become justiciable in different regional and international levels. The CESCR also plays a quasi-judicial role regarding the enforcement of the ESC rights through the reporting system and will soon play an adjudicatory role under the Optional Protocol. The HRC has also enforced certain ESC rights when enforcing certain provisions of the ICCPR as they were found to be interrelated to and interdependent on some ESC rights.

The position on enforceability of ESC rights has changed since the adoption of the ICESCR in 1966. The post 1966 developments indicate that the justiciability of ESC rights now has become an established concept. Shany supports the view that ESC rights 'are internationally justiciable and can be meaningfully enforced by international

\footnotetext{
80 Chairman, National Board of Revenue (NBR) v Advocate Zulhas Uddin Ahmed and others (2010) 15 MLR (AD) 457.

81 Kudrat-E-Elahi Panir v Bangladesh (1992) 44 DLR (AD) 319.
}

Page $\mid 52$ 
Justiciability of Economic, Social and Cultural Rights under International Human Rights Law

courts and tribunals. ${ }^{92}$ It is clear from the above discussion that justiciability of ESC rights is not only possible but is now essential in order to fulfil ICESCR obligations. Furthermore, the above discussion reveals that the current judicial trend of constitutional interpretation in Bangladesh is also in favour of judicial enforceability though in an indirect way.

82 Shany (n 12) 78. 
Dhaka University Law Journal, Centennial Special Issue, Vol. 32(1)

Page | 54 